\title{
Vertical distribution of marine particles and grazers. I. Vertical distribution of food quality and quantity*
}

\author{
J. M. Napp**, E. R. Brooks, F. M. H. Reid, P. Matrai, M. M. Mullin \\ Institute of Marine Resources, A-018, Scripps Institution of Oceanography, University of California, San Diego, La Jolla, \\ California 92093, USA
}

\begin{abstract}
Vertical distributions of marine particle-grazers and their food were measured to examine whether the vertical distribution of food quality was distinct from that of food quantity. In a related paper (Napp et al. 1988) we examine the vertical distribution of particle-grazers in relation to the distributions of food quality and food quantity. During an April cruise in the Southern California Bight there were no differences in the size spectra of food particles between the plant biomass maximum and the region of lower food quantity above it. The species assemblage of microplankton near the surface was more predictable than that at the microplankton biomass maximum, and was distinct from it. Species known to be noxious or distasteful to copepods were not members of either assemblage. The seston at both surface and depth contained unequal proportions of carbohydrate, protein, and lipid. Particulate nitrogen (and protein) per unit carbon was highest at the microplankton biomass maximum, particulate carbohydrate per unit carbon was highest near the surface. Our data provided no obvious reason why particle-grazers might benefit from residing and feeding outside the microplankton biomass maximum.
\end{abstract}

\section{INTRODUCTION}

Marine, particle-grazing zooplankton are thought to live in a 'nutritionally dilute environment' (Conover 1968). Thus, the growth and reproductive success of individuals is determined by their ability to locate anomalous patches of plentiful food (e.g. Anderson et al. 1972, Mullin \& Brooks 1976, Hakanson 1987, Lasker 1975, for ichthyoplankton) and survivorship is determined by their ability to avoid both starvation and predation. It is assumed to be difficult, however, for zooplankton to locate such food-rich patches due to their ephemeral existence; wind-driven mixing and turbulence constantly oppose biological aggregation mechanisms to disperse and destroy the patches (e.g. Kierstead \& Slobodkin 1953).

\footnotetext{
- Dedicated to the memory of Abraham Fleminger

- Present address: University of Miami, Rosenstiel School of Marine and Atmospheric Science, Division of Biology and Living Resources, 4600 Rickenbacker Causeway, Miami, Florida 33149, USA.
}

There is one feature in the oceans, the subsurface chlorophyll a maximum, which seems to be semi-permanent and is often a maximum of phytoplankton biomass (Cullen 1982); this feature is assumed to be food-rich for the herbivorous zooplankton. For this feature to exist, the grazing pressure on it must be less than the light-limited cell growth and contributions due to cells sinking from above (Jamart et al. 1977, Herman \& Platt 1983). The particle-grazer biomass maximum does not appear to be coincident with the subsurface chlorophyll a maximum, but is located shallower, somewhere nearer the depth where the production of plant carbon is greatest (Longhurst 1976, Herman et al. 1981, Fiedler 1983, Roman et al. 1986; cf. Ortner et al. 1980). Feeding also is probably not confined to the chlorophyll a maximum; the gut fullness (pigment content) of individual copepods is poorly correlated with the vertical distribution of chlorophyll a (Dagg \& Wyman 1983, Mullin et al. 1985). Thus we are left with a paradox: if food limits individual growth and reproduction, why do particle-grazers reside and apparently feed above the depth where phytoplankton is relatively more abundant? 
One hypothesis is that food quality is as important as food quantity, and that food is of higher quality in shallower layers. Our goal was to examine the vertical distribution of the food items thought to be important to particle-grazing zooplankton - more specifically to compare the size distribution, species composition, and biochemical attributes of the particulate matter in the plant biomass maximum and in the region above it where specific growth rates are usually higher. The significance of any differences (if they exist) can then be interpreted using recent knowledge of zooplankton growth and behavior in an attempt to explain why zooplankton might not aggregate in a region of locally elevated food concentration. In the companion paper (Napp et al. 1988) we examine the vertical distribution of particle grazers in relation to the distributions of food quality and quantity.

\section{METHODS}

Sampling was accomplished during 1 wk in April (23 to 28,1985 , 'Eumenides III' cruise) in the Southern California Bight, ca $17 \mathrm{~km}$ from the coast in 550 to $790 \mathrm{~m}$ of water (Fig. 1). Twelve continuous-depth profiles of temperature, conductivity, pressure, and in vivo fluorescence were obtained with a Neil Brown CTD/ rosette system to which a Sea Martek fluorometer was attached. Three profiles were obtained each day for the first $2 \mathrm{~d}$; thereafter 2 profiles (morning and night) were sampled each day, weather permitting. Water samples from discrete depths were also obtained through a $10 \mathrm{~cm}$ (ID) plastic pump hose attached to a Honda centrifugal pump (Model WA30). The hose intake was

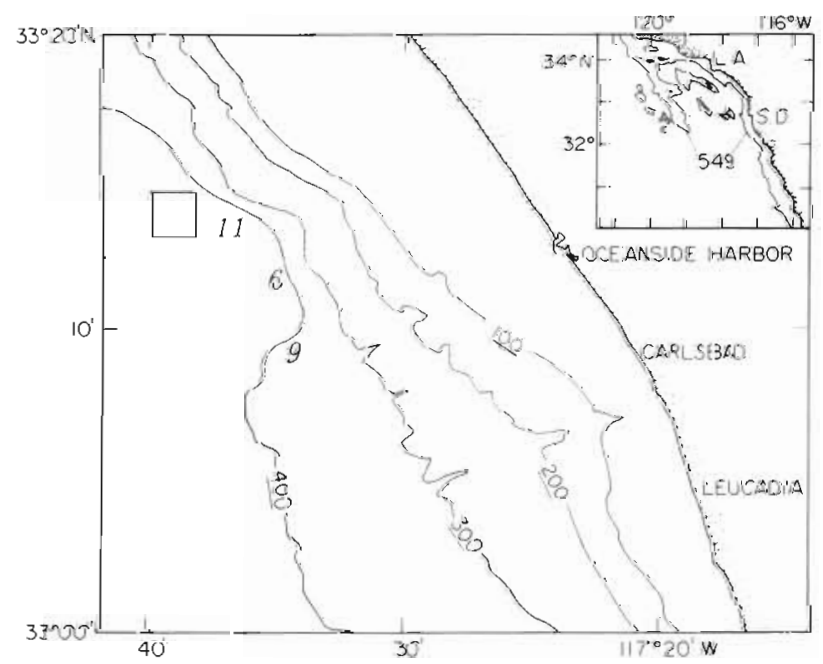

Fig. 1. Station locations for 'Eumenides III'. All vertıcal profiles were sampled from the area contained within the square, except for 2 profiles, 6 and 9 , whose locations are marked. All depths reported in fathoms $(1$ fathom $=1.83 \mathrm{~m})$. L.A. and S.D. are Los Angeles and San Diego, California, respectively clamped to the rosette. Most of the water (ca 6001 $\min ^{-1}$ ) was filtered through a 53 um mesh zooplankton net, but a small fraction of the stream was diverted to fill 1 or 2 plastic carboys from which all subsamples of the seston were drawn. Supplementary samples were obtained with 51 Niskin bottles. No differences were found in measurements of primary production, extracted chlorophyll a, particulate carbon and nitrogen or microplankton carbon between samples collected with the pump and 51 Niskin bottles. Discretedepth measurements of light were made with a Biospherical Instruments (Model \#QSP 170BR) submarine quantum scaler irradiance meter attached to the rosette. A reference irradiance meter was attached to the ship's superstructure.

The CTD/rosette system was slowly lowered through the water beyond the depth of the euphotic zone. Based on the continuous profiles of fluorescence and discrete measurements of submarine light and daily insolation, the depth of the primary productivity maximum was predicted using a linear equation (Napp 1987), and 10 sampling depths were then chosen to span the euphotic zone. The depths of the fluorescence maximum, the predicted depth of the primary productivity maximum, and depths where the temperature profile changed abruptly were always included among the 10 depths. Three methods were used to confirm that our discrete depth pump samples were not aliased by internal waves moving past the bobbing hose intake (Napp 1986). In a small number of instances samples overlapped and the 2 discrete depth samples were considered not independent.

Primary productivity was calculated from the incorporation of ${ }^{14} \mathrm{C}$-bicarbonate by plant cells incubated in situ for 24 h (Eppley et al. 1979). Duplicate bottles were prepared for each depth from the morning pump cast. On one occasion 4 bottles per depth were incubated; the contents of 2 bottles were filtered through $\mathrm{GF} / \mathrm{C}$ filters (1.2 $\mu \mathrm{m}$ nominal pore size), the contents of the other 2 bottles were filtered through Nuclepore $3 \mu \mathrm{m}$ filters. Phytoplankton growth rates $\left(\mu\right.$; doublings $\left.\mathrm{d}^{-1}\right)$ were calculated as

$$
\mu=\log _{2} \text { ([plant carbon + uptake]/plant carbon) }
$$

where phytoplankton carbon was calculated from phytoplankton abundance and volume (see below, Cullen \& Eppley 1981).

Chlorophyll a and phaeopigments were extracted in cold, $90 \%$ acetone for $24 \mathrm{~h}$ in the dark from the particulate matter retained on Whatman GF/C filters and were determined fluorometrically (Strickland \& Parsons 1968). Continuous depth profiles of in vivo fluorescence were transformed into profiles of extracted chlorophyll a using a transfer function. The function is the best least-squares fit of the mean fluorescence (F) dur- 
ing the pumping at each depth to the discrete extracted chlorophyll a sample (Chl) obtained at the same depth $\left(\mathrm{Chl}=0.132 \operatorname{Exp}[0.003 \mathrm{~F}] ; n=83, r^{2}=0.90\right)$.

At 4 of the 10 depths sampled by pump, triplicate subsamples of particulate carbon and nitrogen were obtained, and a single subsample was taken at each of the remaining 6 depths. The water was filtered through precombusted Whatman GF/C filters, which were stored frozen until analysis by gas chromatography using a Hewlitt-Packard model 185B CHN analyzer (Sharp 1974, Eppley et al. 1979).

Subsamples for particulate carbohydrate $(4$ per depth), protein (3 per depth), and lipid (4 per depth) were obtained at 4 of the 10 depths sampled using Whatman GF/C filters. Total carbohydrate was determined after hydrolysis of the seston ( $80 \%$ concentrated $\mathrm{H}_{2} \mathrm{SO}_{4}$ for $>16 \mathrm{~h}$; Dubois et al. 1956). Total protein was determined using the Biuret-Folin procedure (Dorsey et al. 1977) and was standardized against bovine serum albumin (Sigma Chemicals). The analytical precision of this technique was greater than that for the determination of carbohydrate or lipid, hence less replication was required. Lipids were first extracted in an acidified chloroform:methanol $(1: 2)$ solution (Dubinsky \& Aaronson 1979). After separation, isolation, and evaporation of the lipid-containing solvent, the amount of lipid was determined after oxidation by potassium dichromate (Pande et al. 1963). Palmitic acid (Sigma Chemical) was chosen as the standard after determining that the method did not respond differentially to equivalent amounts of stearic acid, cholesterol, or palmitic acid.

A subsample of the water was also preserved in $2 \%$ buffered formalin for microscopical analysis. Plant cells and microzooplankton, 2 to $200 \mu \mathrm{m}$ (hereafter referred to as microplankton), were identified and enumerated, and the resultant counts were converted to biomass using a volume-to-carbon equivalence (Strathmann 1967, Reid 1983).

\section{RESULTS}

\section{General description}

Returning to the same station for each cast, we sampled from surface waters which were flowing past us, usually in a southeasterly direction. Thus the daily changes in the physical and biological properties of the water column were due to both local and advective processes.

The subsurface chlorophyll a maximum was usually found within or just below the main density discontinuity (indicated by the depth of the maximum Brunt-
Fig. 2. Profiles 2, 3, and 4. Vertical distributions of (A) temperature ("C) and density (sigma, $\mathrm{S}$, $T, P),(B)$ Brunt-Väisälä frequency

$\left(\operatorname{cph} ; N=\left(g\left(-\frac{1}{\rho} \frac{\partial \rho}{\partial z}-\frac{g}{C^{2}}\right)\right)^{2 / 2} / 2 \pi\right.$ where $g=$ gravitational acceleration, $\rho=$ density, $C=$ speed of sound in seawater), (C)

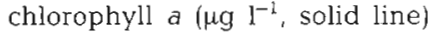
and primary productivity $(\mathbf{\Lambda}, \mathrm{mg}$ $\mathrm{C} \mathrm{m}^{-3} \mathrm{~d}^{-1}$ ), and (D) particulate carbon $(\odot)$ and nitrogen $(\mathbf{A})(\mu \mathrm{g}$ $\left.1^{-1}\right)$. Depths of preserved microplankton samples used in the analysis are indicated on the chlorophyll a profiles by an arrow

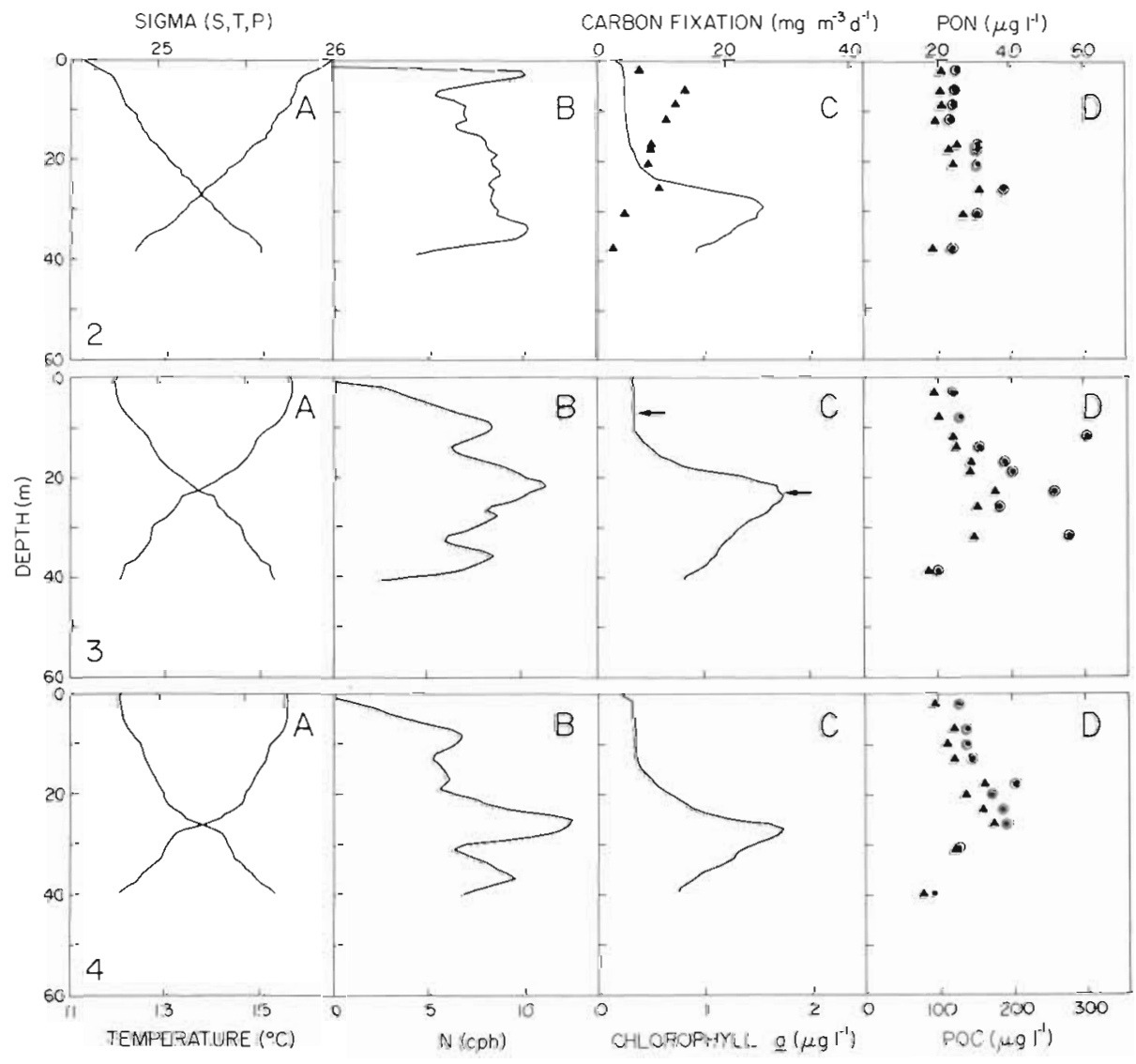


Väisälä frequency; Figs. 2 to 6). However, that depth (and isopycnal) varied during the cruise. The maximum concentration of chlorophyll a increased from 1.6 to 2.4 $\mu \mathrm{gl}^{-1}$ during the week. The degree of stratification of chlorophyll a also varied, though in general, the con- centration gradient between the surface and the subsurface maximum was steep.

The vertical distribution of primary production was usually maximal just above the subsurface chlorophyll maximum (Figs. 2 to 6 ). The phytoplankton growth rate

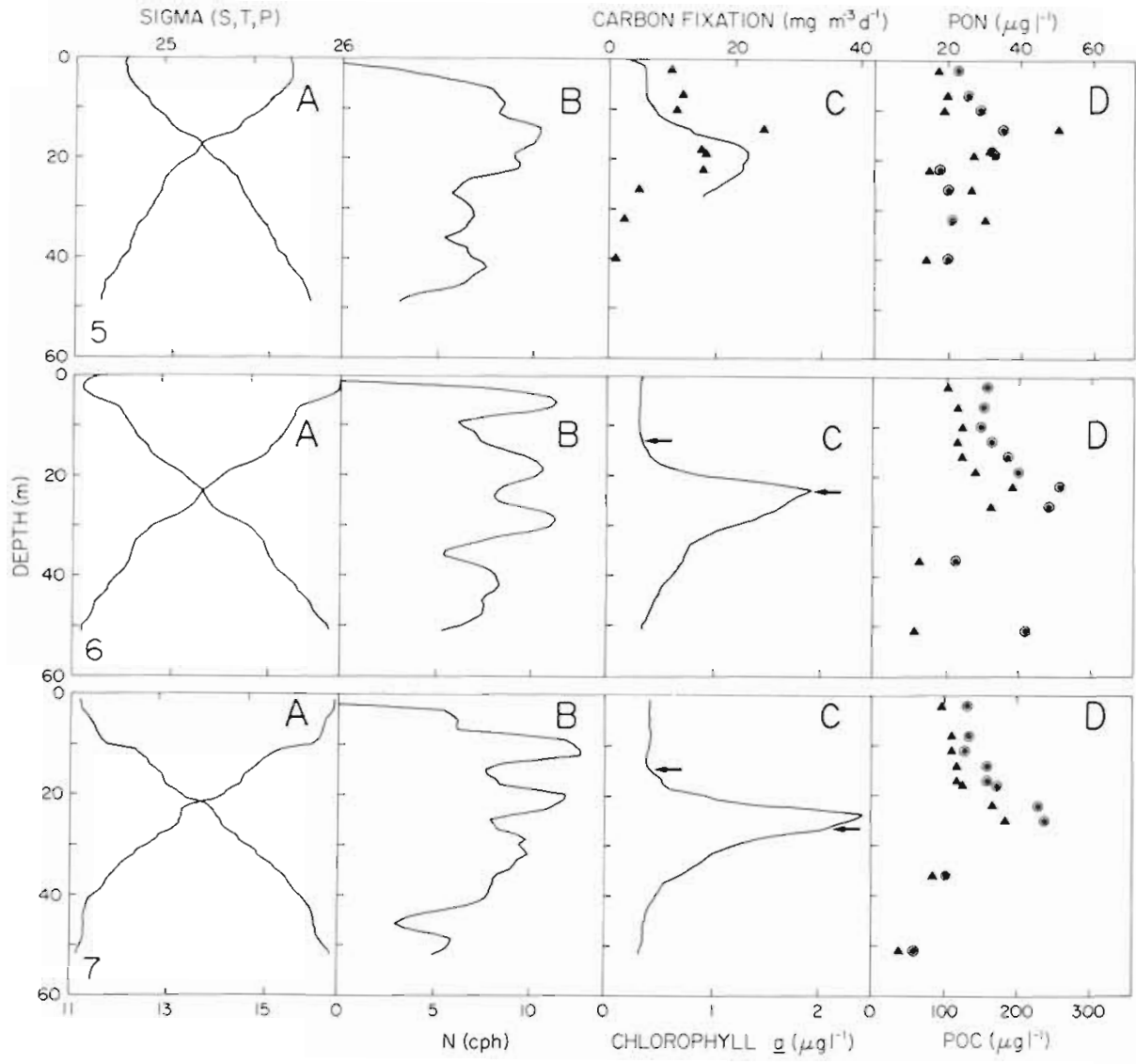

Fig. 3. Profiles 5, 6, and 7 As for Fig. 2

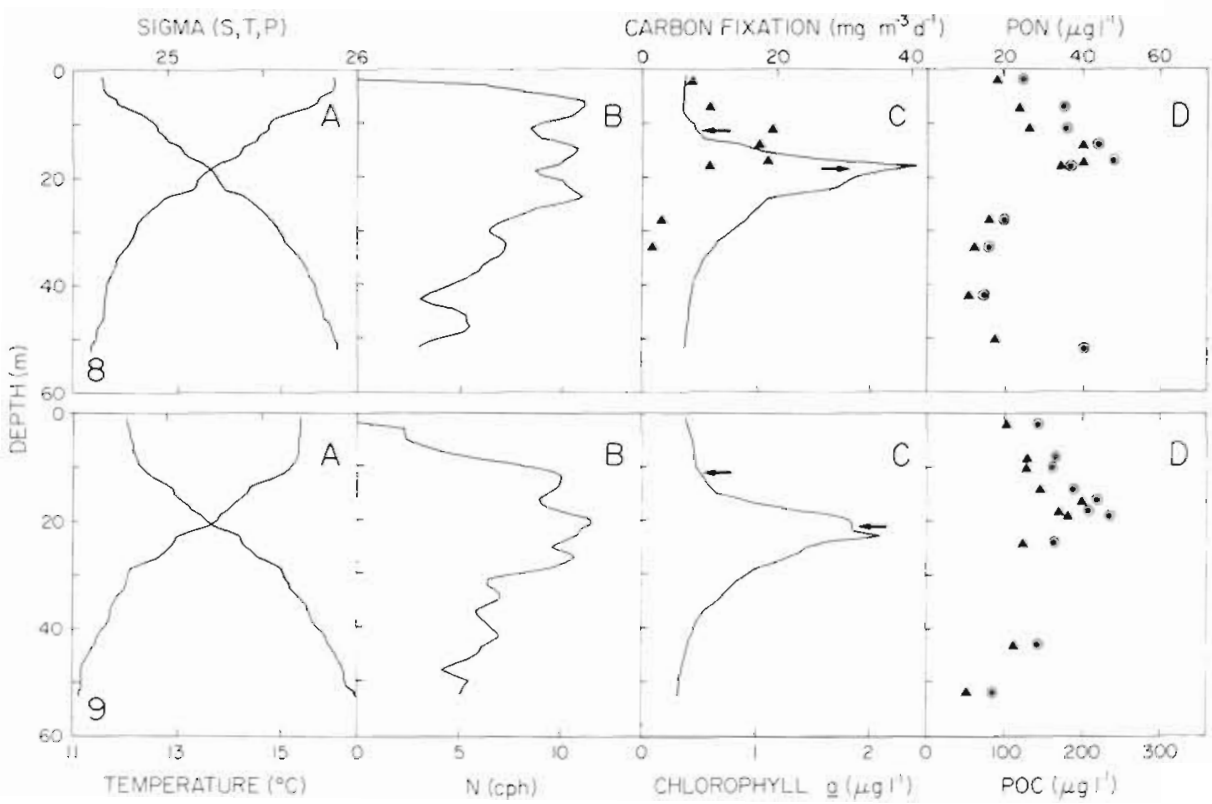

Fig. 4. Profiles 8 and 9. As tor Fig. 2 
was also usually the greatest in the waters above the chlorophyll a maximum. In addition, a large fraction of the primary production occurred in cells which may have been too small $(<3 \mu \mathrm{m})$ to be used effectively as food by many meso- and macrozooplankton (Fig. 5, Cast 12).

\section{Concordance between biomass indices}

It is important to be able to distinguish regions of high from low microplankton biomass (food for the particle-grazers). Chlorophyll $a$ is not produced in strict proportion to plant biomass, and the microplankton is

Fig. 5. Profiles 10 and 12. As for Fig. 2. In 12 (C): (4) GF/C filters; (O) $3 \mu \mathrm{m}$ Nuclepore filters
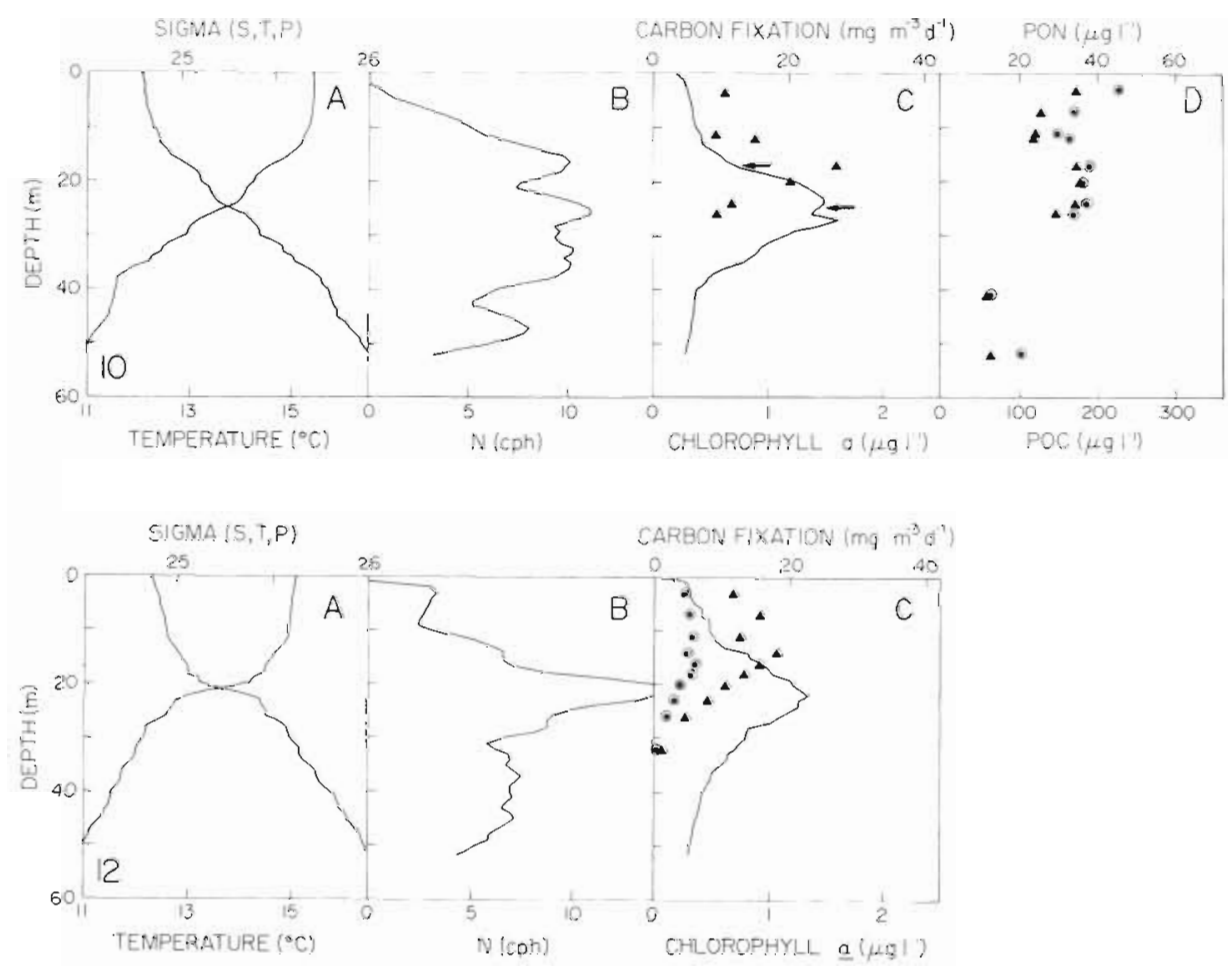

Fig. 6. Profiles 13 and 14. As for Fig. 2

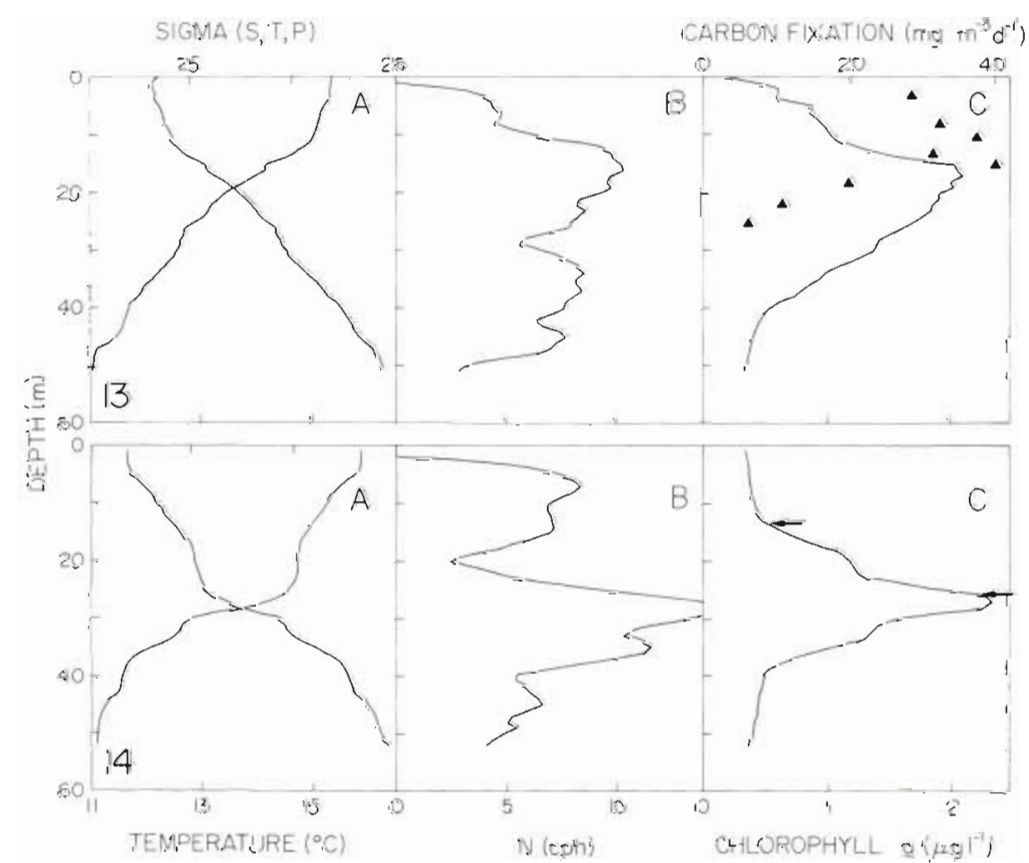



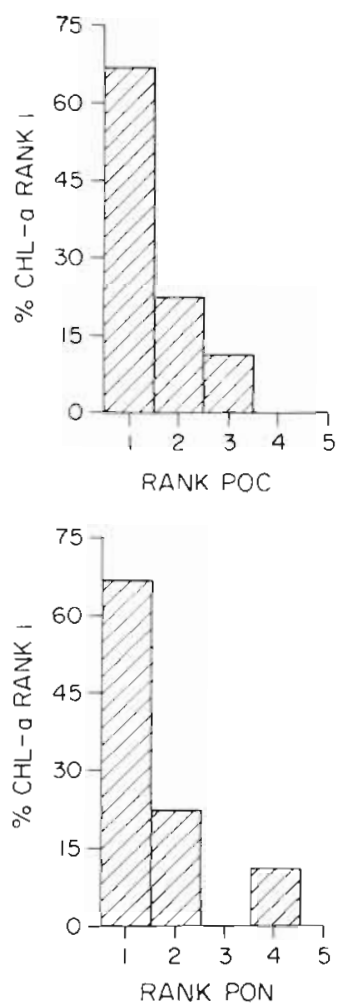

Fig. 7. Microplankton biomass concordance. Percent spatial coincidence of the chlorophyll a and particulate carbon maxima, (top panel) and the chlorophyll $a$ and particulate nitrogen. maxima (bottom panel)

composed of microzooplankton as well as phytoplankton. Chemical measurement of total particulate matter (seston) includes non-living detritus as well as plankton. Thus it is necessary to compare several indirect indices of microplankton biomass for agreement.

During 'Eumenides III', the depth with the largest quantity of chlorophyll a also had the greatest measurable quantity of particulate carbon and nitrogen about $2 / 3$ of the time (Fig. 7). However, a difference between profiles in the concentration of pigment at the chlorophyll a maximum did not result in a proportional change in the concentration of particulate carbon and nitrogen, as the concentrations of chlorophyll, particulate carbon and nitrogen at the chlorophyll a maximum were not concordant from cast-to-cast (Kendall's $W=$ $0.53,0.05<p<0.10$ ). However the vertical distributions of particulate carbon, measured at different times, were concordant when the data from each cast were ranked according to the vertical distribution of chlorophyll $a$ in that cast ( $n=9$ profiles, Kendall's $W=$ $0.40, p \ll 0.01$ ). Thus the vertical distribution of particulate carbon is in consistent agreement with itself with respect to the chlorophyll a profiles. The same was true for particulate nitrogen $(n=9, W=56, p \ll 0.01)$, but not primary productivity $(n=3, W=0.21, p>0.20)$.
Table 1 Phytoplankton growth rates (doublings $\mathrm{d}^{-1}$ ) from regions of low (shallow) and high plant biomass (chlorophyll a maximum). Vertical distance (m) between the samples also given. When primary productivity was not measured, or the position of the chlorophyll a maximum changed relative to the density field, phytoplankton growth rates were not determined (ND)

\begin{tabular}{|cccc|}
\hline Cast & $\begin{array}{c}\text { Separation } \\
(\mathrm{m})\end{array}$ & Shallow & $\begin{array}{c}\text { Chlorophyll a } \\
\text { maximum }\end{array}$ \\
\hline $3^{\mathrm{a}}$ & 15 & 0.86 & 0.35 \\
6 & 9 & $\mathrm{ND}$ & $\mathrm{ND}$ \\
7 & 13 & $\mathrm{ND}$ & $\mathrm{ND}$ \\
8 & 6 & 0.67 & 0.51 \\
$9^{\mathrm{a}}$ & 9 & 0.67 & 0.51 \\
10 & 7 & 0.83 & 0.43 \\
14 & 11 & $\mathrm{ND}$ & $\mathrm{ND}$ \\
a & \multicolumn{4}{l}{} \\
Rates from a previous cast where primary productivity \\
was measured along the same isopycnal \\
\hline
\end{tabular}

\section{Microplankton carbon}

Enumeration of microplankton is laborious, so we obtained estimates of microplankton carbon at only 2 or 3 depths for each of 7 profiles. Within each profile, a sample from the chlorophyll a maximum and one from above that feature were chosen for analysis. The latter samples often came from a region of higher primary production and higher phytoplankton growth rate (Table 1).

Overall, the concentration of microplankton was significantly higher at the depth of the chlorophyll a maximum than at a shallower depth (Signed Ranks, $n=7$, $p=0.02$ ) and most of the microplankton biomass was phytoplankton biomass. Thus the chlorophyll a maximum was a site of high food concentration for the zooplankton both in terms of plant and microplankton biomass. Microscopically recognizable microplankton carbon was only a small fraction of the total particulate carbon $($ Median $=15 \%$, Range $=9.9$ to $27 \%$ ) although a greater contribution was suggested when the concentration of chlorophyll a was used to estimate plant carbon $($ Median $=52 \%$, Range $=16$ to $83 \%$; plant carbon/chlorophyll $=75$, wt: wt, as suggested by Eppley et al. 1977, their Table 2).

Particle size is another criterion to test for differences in types of food available to the grazers in different parts of the water column. In general, the microplankton cells present during the cruise were small; there was a virtual absence of cells larger than $60 \mu \mathrm{m}$ equivalent spherical diameter (ESD, Fig. 8)

Two different tests were conducted to determine whether the size spectra of microplankton cells differed between the chlorophyll a maximum and the region above it (Table 2). In the first, taxa $(<20 \mu \mathrm{m}$ ESD) were 


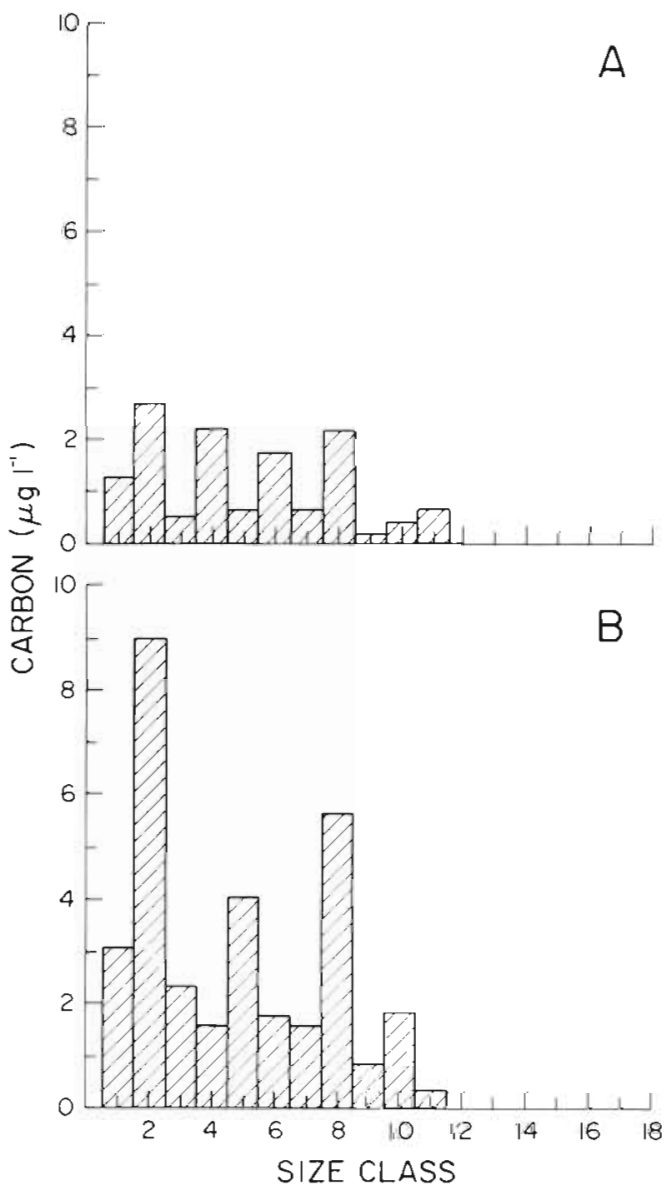

Fig. 8. Size distribution of microplankton biomass. Distribution from 2 samples from a single profile (3). (A) Sample \#1739 from a region of low plant biomass; (B) sample \#1734 from the chlorophyll a maximum. Size categories (ESD, $\mu \mathrm{m}$ ): $1,2-4 ; 2$, $>4-7 ; 3,>7-10 ; 4,>10-13 ; 5,>13-17 ; 6,>17-22 ; 7$, $>22-28 ; 8,>28-36 ; 9,>36-46 ; 10,>46-58 ; 11,>58-74 ; 12$, $>75-93 ; 13,>93-117 ; 14,>117-146 ; 15,>146-184 ; 16$, $>184-232 ; 17,>232$

Table 2. Probabilities associated with Sign Tests between the size frequency spectra of samples from the microplankton biomass maximum and the region above it. Depths of samples noted on chlorophyll a profiles (Figs. 2 to 6 )

\begin{tabular}{|ccc|}
\hline Cast & \multicolumn{2}{c|}{ Bin size } \\
& $\begin{array}{c}50 \mu \mathrm{m}^{3} \\
\left(0-5000 \mu \mathrm{m}^{3}\right)\end{array}$ & $\begin{array}{c}1000 \mu \mathrm{m}^{3} \\
\left(0-617000 \mu \mathrm{m}^{3}\right)\end{array}$ \\
\hline 3 & $<0.01$ & 0.50 \\
6 & 0.05 & 0.05 \\
7 & 0.16 & 0.18 \\
$8^{a}$ & 0.15 & 0.01 \\
9 & 0.07 & 0.07 \\
10 & 0.33 & 0.42 \\
& & \\
a Sample located above the chlorophyll a maximum which \\
was also in a region of elevated chlorophyll concentration
\end{tabular}

Table 3. Taxa of microplankton ( 2 to $200 \mu \mathrm{m}$ ) considered to be common among samples examined. Size category is the nominal category used by the observer Equivalent spherical diameter (ESD) calculated from average volume of that taxon

\begin{tabular}{|c|c|c|}
\hline Taxon & $\begin{array}{c}\text { Size } \\
\text { category }\end{array}$ & $\begin{array}{l}E S D \\
\{\mu \mathrm{m}\}\end{array}$ \\
\hline \multicolumn{3}{|l|}{ Pennate diatoms } \\
\hline Cylindrotheca closterium & -10 & 2.9 \\
\hline C. closterium & -20 & 3.7 \\
\hline C. closterium & -30 & 4.2 \\
\hline Nitzschia 'seriata' & $40-49$ & 4.8 \\
\hline N. 'seriata' & $60-69$ & 7.2 \\
\hline N. 'seriata' & $80-89$ & 9.5 \\
\hline Nitzschia sp. R & & 7.7 \\
\hline Pennates (unidentified) & $5-9$ & 2.8 \\
\hline Pennates (unidentified) & $10-19$ & 5.4 \\
\hline Pennates (unidentified) & $50-59$ & 18.3 \\
\hline \multicolumn{3}{|l|}{ Centric diatoms } \\
\hline Chaetoceros spp. (small) & & 10.7 \\
\hline Chaetoceros spp. (large) & & 15.1 \\
\hline Discoids (unidentified) & $5-9$ & 6.4 \\
\hline Discoids (unidentified) & $20-29$ & 20.3 \\
\hline Rhizosolenia alata (small) & & 32.6 \\
\hline \multicolumn{3}{|l|}{ Thecate dinoflagellates } \\
\hline$\overline{\text { Ceratium lineatum }}$ & & 22.5 \\
\hline Thecates (unidentified) & $5-9$ & 6.9 \\
\hline Thecates (unidentified) & $10-19$ & 14.6 \\
\hline Thecates (unidentified) & $20-29$ & 23.4 \\
\hline Thecates (unidentified) & $30-39$ & 32.5 \\
\hline \multicolumn{3}{|l|}{ Non-thecate dinoflagellates } \\
\hline Gyrodinium spp. C-F & & 11.6 \\
\hline Gytodinium spp. $\mathrm{C}-\mathrm{G}$ & & 19.3 \\
\hline Gyrodinium spp. C-H & & 27.5 \\
\hline Naked dinoflagellates (unidentified) & $5-9$ & 5.1 \\
\hline Naked dinoflagellates (unidentified) & $10-19$ & 8.4 \\
\hline Naked dinoflagellates (unidentified) & $20-29$ & 14.2 \\
\hline Naked dinoflagellates (unidentified) & $30-39$ & 19.1 \\
\hline Naked dinoflagellates (unidentified) & $40-49$ & 25.0 \\
\hline \multicolumn{3}{|l|}{ Coccolithophorids } \\
\hline Coccolithophorids (unidentified) & $<5$ & 3.0 \\
\hline Coccolithophorids (unidentified) & $5-9$ & 7.5 \\
\hline Coccolithophorids (unidentified) & $10-15$ & 13.0 \\
\hline Emiliania huxleyi & & 6.5 \\
\hline Helicosphaera carterae & & 23.0 \\
\hline Syracosphaera pulchra & & 19.9 \\
\hline \multicolumn{3}{|l|}{ Monads and flagellates } \\
\hline Chilomonas marina & & 7.0 \\
\hline Monads and flagellates & $2-4$ & 3.3 \\
\hline Monads and flagellates & $5-7$ & 6.2 \\
\hline Monads and flagellates & $8-12$ & 10.4 \\
\hline \multicolumn{3}{|l|}{ Other } \\
\hline 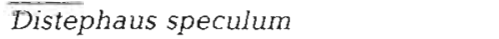 & & 17.2 \\
\hline Eutreptiella gymnastica & & 15.0 \\
\hline \multicolumn{3}{|l|}{ Microzooplankton } \\
\hline Laboea spp. (small) & & 15.0 \\
\hline Laboea spp. & $20-29$ & 25.3 \\
\hline Laboea spp. & $30-39$ & 35.1 \\
\hline Laboea spp. & $40-55$ & 48.7 \\
\hline Lohmanniella spp. (small) & & 15.0 \\
\hline Lohmanniella spp. & $20-29$ & 25.3 \\
\hline Lohmanniella spp. & $30-39$ & 35.1 \\
\hline Mesodinium rubrum & & 29.9 \\
\hline Salpingella & & 11.6 \\
\hline Tintinnids & $10-50$ & 31.6 \\
\hline Unidentified ciliates (large) & & 24.2 \\
\hline
\end{tabular}


assigned to bins, $50 \mathrm{um}^{3}$ in size, based on cell volume (i.e. bin \#1=0.1 to $50 \mu^{3}$, bin $\# 2=50.1$ to $100 \mu \mathrm{m}^{3}$, etc.). For each sample, the fraction of microplankton carbon contained within each bin was calculated and then compared between samples. For the second test, taxa from the entire size spectrum (0 to $106 \mu \mathrm{m}$ ESD) were assigned to bins $1000 \mu^{3}$ in size. Assignment by total volume neglects differences in cell shape, as cells with the same volume may have very different linear dimensions. There were no consistent differences in the size spectrum of microplankton between samples from the same pump cast (Table 2). Thus there was insufficient evidence to conclude that the size spectra of

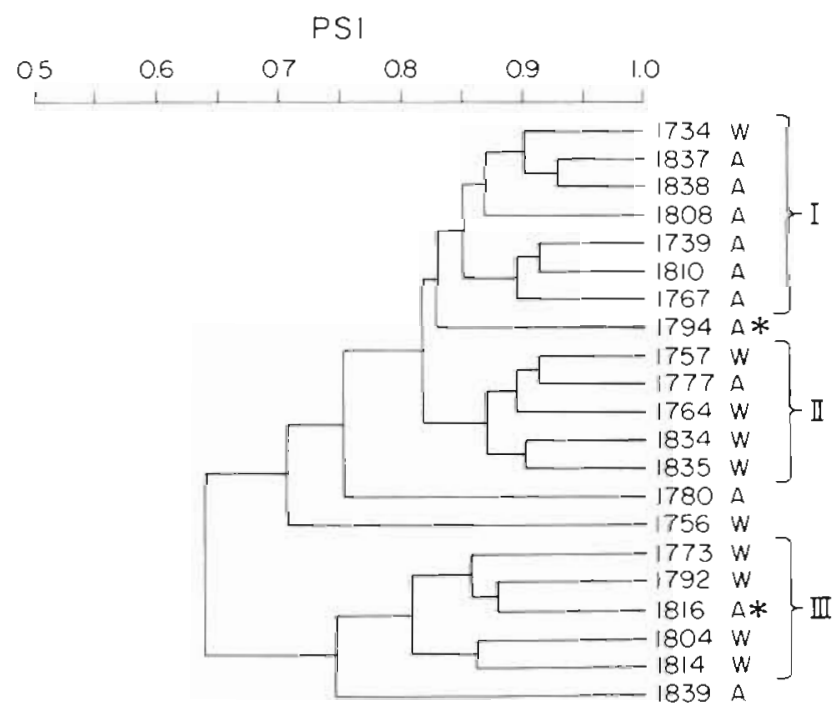

Fig. 9. Dendrogram of samples from within (W) and above (A) the chlorophyll a maximum. Samples were clustered using a weighted-pairs algorithm according to the similarity of the numerical abundance of common taxa between samples. - Samples from above chlorophyll a maximum in a region of high plant biomass. See text for explanation of groups I to III microplankton carbon differed systematically between the chlorophyll a maximum and the region above it.

In general, the phytoplankton assemblage present during our cruise was unusual for this region; it consisted of small cells and lacked an easily identifiable, single dominant species. Thus for our analysis it was necessary to use broader groups of taxa (e.g. unidentified pennate diatoms, unidentified discoid diatoms, unidentified thecate dinoflagellates) separated into size categories (Table 3 ).

Microplankton carbon is packaged in many different sizes and shapes which loosely correspond to species or species groups. To determine if the distribution of different food types (the menu, as it were) was heterogeneous within the water column, we compared the similarity between the microplankton species assemblages at the chlorophyll a maximum and the region above it where food was less plentiful.

The similarity between samples was calculated separately for numerical abundance and biomass of cells using the Percent Similarity Index (PSI, Whittaker 1952). Only those taxa which were relatively common were used. The samples were ordered (clustered) according to their similarity using the weighted pairgroup algorithm of Sokal \& Sneath (1963). The PSI of numerical abundance (but not biomass) separated the samples into recognizable groups (Fig. 9). Group I was comprised of 7 samples, all from above the chlorophyll a maximum, save one: \#1734. Group II was comprised of 5 samples, all from within the chlorophyll a maximum, except one: \#1777. Group III, whose average similarity was less than the other groups, was composed of 4 samples from within the chlorophylla maximum and 1 sample from above that feature, but still in a region of high chlorophyll. Four samples were not included in the groups: \#1756, \#1780, \#1794, and \#1839.

Table 4. Comparison of average Percent Similarity Indices of samples within and between the chlorophyll a maximum and the region above it. $T$-statistic and its critical value $\left(T_{\text {crit }}\right)$ were calculated for unequal sample sizes assuming unequal variances and $\alpha$ $=0.01$. CHLMX: depth of chlorophyll maximum; SW: surface waters above chlorophyll maximum

\begin{tabular}{|c|c|c|c|c|c|c|c|c|c|}
\hline & $N$ & Mean & $s^{2}$ & & $N$ & Mean & $S^{2}$ & $T$ & $T_{\text {crit }}$ \\
\hline \multicolumn{10}{|l|}{ Abundance (no. $\mathrm{I}^{-1}$ ) } \\
\hline CHLMX vs CHLMX & 45 & 77.7 & 54.4 & SW vs SW & 28 & 83.5 & 19.7 & 4.19 & 272 \\
\hline CHLMX vs CHLMX & 45 & 77.7 & 54.4 & CHLMX vs SW & 80 & 75.9 & 60.6 & 1.28 & 2.66 \\
\hline SW vs SW & 28 & 83.5 & 19.7 & CHLMX vs SW & 80 & 75.9 & 60.6 & 6.29 & 2.68 \\
\hline $\begin{array}{l}\text { CHLMX vs SW } \\
\text { (same station) }\end{array}$ & 8 & 74.6 & 100.3 & $\begin{array}{l}\text { CHLMX vs SW } \\
\text { (different stations) }\end{array}$ & 72 & 76.0 & 57.4 & 0.38 & 3.45 \\
\hline \multicolumn{10}{|l|}{ Biomass $\left(\mu g \mathrm{Cl}^{-1}\right)$} \\
\hline CHLMX vs CHLMX & 45 & 61.2 & 59.6 & SW vs SW & 28 & 59.4 & 95.3 & 0.83 & 2.75 \\
\hline CHLMX vs CHLMX & 45 & 61.2 & 59.6 & CHLMX vs SW & 80 & 57.5 & 84.5 & 2.40 & 2.65 \\
\hline SW vs SW & 28 & 59.4 & 95.3 & CHLMX vs SW & 80 & 57.5 & 84.5 & 0.90 & 2.73 \\
\hline $\begin{array}{l}\text { CHLMX vs SW } \\
\text { (same station) }\end{array}$ & 8 & 62.7 & 35.1 & $\begin{array}{l}\text { CHLMX vs SW } \\
\text { (different stations) }\end{array}$ & 72 & 56.2 & 87.2 & 2.45 & 3.32 \\
\hline
\end{tabular}


To test for differences in a more rigorous way, the average PSI for samples within and above the chlorophylla maximum were compared (Table 4). Samples from different profiles which came from above the chlorophyll a maximum were more similar in species composition than those from within the maximum. The similarity of samples from above the chlorophyll a maximum was also greater than the average similarity of samples from both regions. Thus the phytoplankton assemblage above the region of elevated microplankton biomass was an identifiable entity. No such differences were evident when the similarity of samples from different regions was calculated using plant biomass (carbon) instead of numerical abundance.

To this point, it appears that the chlorophyll a maximum we sampled was also a maximum of particulate carbon and nitrogen, and was distinguishable from shallower waters by floral composition but not by particle size.

\section{Nutritional content}

The nutritional content of phytoplankton cells is known to vary as a function of light and nutrient availability. Our question was, does the nutritional content of the seston (phytoplankton, bacteria, detritus) vary with depth in a predictable manner, as does the distribution of light (decreasing with depth) and nutrients (increasing with depth)?

The particulate seston differed in protein and carbohydrate content between the surface and the chlorophyll a maximum but in opposing directions; protein per unit carbon was higher at the microplankton biomass (chlorophyll a) maximum, while carbohydrate was higher at the surface (Table 5, Sign Test, $n=9$, $p<0.02$, for each). Total lipid was not enriched differentially between depths (Sign Test, $p>0.16$ ).

Nitrogen enrichment of the seston at the chlorophyll a maximum was also apparent from the particu-

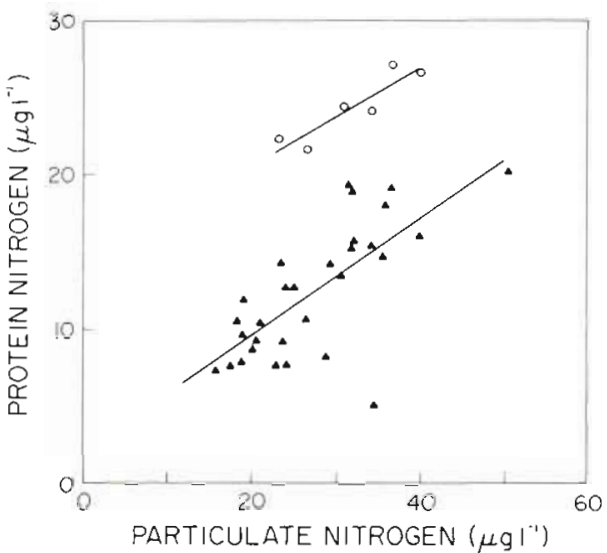

Fig. 10. Protein-nitrogen versus particulate nitrogen. Weight of protein-nitrogen was taken to be $15.5 \%$ the weight of protein. Six points $(0)$ form a distinct line; the 2 lines share a similar slope but have different intercepts (see text). All sam. ples (both $\circ$ and 4 ) were obtained in exactly the same way

late carbon to nitrogen ratio (Sign Test, $n=9, p<0.02$ ) as expected from the protein/carbon pattern. However, the protein-nitrogen content of the seston (assuming that $15.5 \%$ of the weight of protein is nitrogen) was not a constant fraction of the total particulate nitrogen (Fig. 10). Six of the 36 points form a distinct line similar in slope but different in intercept than the regression calculated for the other 30 points (Analysis of Covariance, $p>0.75$ and $p<0.05$ respectively). Five of these 6 samples are from the lower part of the euphotic zone ( $\leq 6 \%$ light), and 4 of these 5 are from the chlorophyll a maximum.

\section{DISCUSSION}

Our goal was to examine the vertical distribution of food items of particle-grazing zooplankton for differences in size, type, or nutritional content which might influence the vertical distribution and grazing rates of

Table 5. Chemical composition of particulate matter at $2 \mathrm{~m}$ (I) and at the chlorophyll a maximum (II)

\begin{tabular}{|c|c|c|c|c|c|c|c|c|}
\hline \multirow[t]{2}{*}{ Cast } & \multicolumn{2}{|c|}{ Protein/Carbon } & \multicolumn{2}{|c|}{ Carbohydrate/Carbon } & \multicolumn{2}{|c|}{ Lipid/Carbon } & \multicolumn{2}{|c|}{$C: N$} \\
\hline & I & II & I & II & I & II & I & II \\
\hline 2 & 0.54 & 0.80 & 0.71 & 1.0 & 0.40 & 0.30 & 7.4 & 7.1 \\
\hline 3 & 0.42 & 0.37 & 0.59 & 0.58 & 0.07 & 0.28 & 7.4 & 8.4 \\
\hline 4 & 0.49 & 1.3 & 0.73 & 0.56 & 0.21 & 0.41 & 7.4 & 6.4 \\
\hline 5 & 0.44 & 0.74 & 0.74 & 0.62 & 0.18 & 0.17 & 7.5 & 4.2 \\
\hline 6 & 0.36 & 0.42 & 0.76 & 0.76 & 0.19 & 0.12 & 8.9 & 7.7 \\
\hline 7 & 0.60 & 0.74 & 0.49 & 0.38 & 0.49 & 0.22 & 7.6 & 7.6 \\
\hline 8 & 0.56 & 0.72 & 0.46 & 0.30 & 0.01 & 0.13 & 8.0 & 6.7 \\
\hline 9 & 0.43 & 0.53 & 0.58 & 0.40 & 0.14 & 0.13 & 7.9 & 7.4 \\
\hline 10 & 0.15 & 0.54 & 0.37 & 0.33 & 0.06 & 0.01 & 7.5 & 6.1 \\
\hline
\end{tabular}


the zooplankters, and confer an advantage in feeding at a particular depth. Our original intention was to compare the phytoplankton species assemblages and the biochemistry of the seston within the plant biomass (microplankton) and primary productivity maxima. However, we have settled on a less specific comparison: the plant biomass maximum versus a shallower depth of lower plant biomass but an equal or greater phytoplankton growth rate. This was done because: (1) it was not possible to determine the depth of the primary productivity maximum from a continuous profile, as can be done for chlorophyll fluorescence; (2) it is doubtful that the zooplankton can directly assess the growth rate of phytoplankton cells; (3) the majority of the production at the primary productivity maximum was due to cells too small $(<3 \mu \mathrm{m})$ for most particle-grazers (copepods, in particular) to use effectively (Bartram 1981).

\section{Microplankton}

Our list of 51 common taxa had little in common with lists of important taxa from other studies of the same region (Reid et al. 1978, Cullen et al. 1982, Goodman et al. 1984, Reid et al. 1985). Beginning in late 1982 the California coastal waters experienced El Niño; the water temperature rose and phytoplankton production was reduced. Chlorophyll a, measured at the end of the SIO pier, was consistently low from mid 1983 to March 1985 with no significant pulses of increased biomass. (J. McGowan pers. comm.). The concentration of chlorophylla measured at the SIO pier began to increase prior to our cruise and continued to do so for at least $1 \mathrm{wk}$ after we returned. However, the absence of large phytoplankters seen in our samples is characteristic of the size spectrum of cells present during El Niño.

None of the taxa common to these samples are known to be deleterious to or are unsuitable as food for particle-grazers (Huntley et al. 1986). In addition, very large spiny cells such as Chaetoceras spp., which may be relatively more difficult to handle and ingest (e.g. Parsons et al. 1967, Conover \& Mayzaud 1984), were not important in our samples.

As expected, a large fraction of the microplankton carbon was contained in cells less than 20 um ESD (Beers et al. 1980; Reid 1983, Table II, Set 10a \& b). However, the size spectra of microplankton were not predictably different between the plant biomass maximum and the region above it where plant biomass was lower and cell growth rates were often greater. Differences in size spectra have been reported between the subsurface chlorophyll a maximum and the surface (Reid 1983, Set 10a \& b) and between the deep chlorophyll maximum and the mixed layer (Revelante
\& Gilmartin 1973, Gieskes \& Kraay 1986). However, it has also been observed locally that the fraction of chlorophyll contained in large particles ( $\geq 5 \mathrm{um}$ ) did not vary as a fraction of plant biomass (i.e. that the size spectrum of chlorophyll-containing cells within the maximum was not different from that outside this feature (Mullin \& Brooks 1976, Mullin 1979). In the present study, using size as the criterion, the food available to grazers at the plant biomass maximum was not different from that nearer the surface.

Differences in the specific packaging of the particulate carbon may also contribute to differences in taste or desirability of the cells to the grazers, and differences between microplankton taxa within the subsurface chlorophyll maximum and those at the surface have been observed in the Southern California Bight (Reid et al. 1978, Beers et al. 1980, Cullen et al. 1982). In the oligotrophic oceans, where the deep chlorophyll maximum (DCM) is usually a symptom of shade-adaption and is not a plant biomass maximum, different species assemblages exist in the mixed layer and the deep chlorophyll maximum (Revelante \& Gilmartin 1973, Venrick et al. 1973, Beers et al. 1982, Furuya \& Marumo 1983, Gieskes \& Kraay 1986). However, closely spaced samples have indicated that the transition zone between the 2 assemblages is located either on the upper shoulder, or directly within the DCM (Gieskes \& Kraay 1986, Venrick 1982, respectively).

During this study, the microplankton assemblage (based on cell abundance) in the surface waters was distinct from, and more coherent than, that at the plant biomass maximum. This was not true when microplankton biomass was considered. These results are contrary to those of Cullen et al. (1982) who found a distinct and more coherent assemblage in the subsurface chlorophyll maximum than at the surface, based on both abundance and biomass. At that time, however, Ceratium tripos dominated a multispecies dinoflagellate patch in the subsurface chlorophyll maximum (Eppley et al. 1984). Thus during 'Eumenides III', the relative composition of the food items available to particle-grazers was more constant near the surface than at the plant biomass maximum.

\section{Biochemical components}

Phytoplankters are protein-producing cells which manufacture carbohydrates and/or lipids as storage products. When illuminated with strong light and deprived of nitrogenous nutrients for a sufficiently long period, as in stratified waters after a spring bloom, protein production declines and the production of storage products increases (Morris 1981). The effects of short-term nitrogen deprivation on protein production 
is less clear. The fraction of carbon incorporated into protein may increase with depth (Li \& Platt 1982, Barlow 1984a; cf. Harding et al. 1985) or decreasing light (Hitchcock et al. 1986; cf. Redalje \& Laws 1983). Further, the metabolism of different species may react differently to the same environmental changes (e.g. Li \& Platt 1982, Dortch et al. 1984, Harding et al. 1985, Rivkin 1985; cf. Morris 1981). In contrast to carbohydrate and lipid, protein production is more constant during the photocycle; protein is synthesized day and night at the expense of storage products synthesized during the day (e.g. Morris \& Skea 1978, Hitchcock 1980, Li \& Harrison 1982, Terry et al. 1983, Barlow 1984b, Cuhel et al. 1984, Harding et al. 1985, Rivkin $1985)$.

In this study, we measured the absolute concentration of the 3 major biochemical components (carbohydrate, protein, lipid) rather than their relative rates of production. That is, we were more interested in the present, than future, nutritional content of the seston Less is known about the vertical distribution of the nutritional content of cells than about the rate of macromolecule production (but see Handa \& Tominaga 1969). We found that the vertical distributions of carbohydrate per unit carbon and nitrogen per unit carbon had opposite trends; the former decreased with depth while the latter increased. Protein enrichment of particulate carbon resulted in greater nitrogen to carbon ratios at depth than at the surface (cf. Dortch 1987).

Our data are an average of all ratios for the individual particles retained by the filters we used. However, filters are less selective the grazers might be, thus not all particles that contributed to our measurements were available to the grazers as food. Bacteria which have lower $\mathrm{C}: \mathrm{N}$ ratios (4 to 5 ) than phytoplankton and are often most abundant in the chlorophyll a maximum (Fuhrman et al. 1980) are not retained efficiently by the filters we used (Azam \& Hodson 1977). Thus the lower $\mathrm{C}: \mathrm{N}$ and higher protein : $\mathrm{C}$ ratios observed within the chlorophyll maximum were probably not the result of free-living bacteria which are unavailable to most zooplankton (copepods) as food.

\section{Zooplankton feeding and nutrition}

In the laboratory copepods have been observed to clear water of large particles at a faster rate than smaller particles (e.g. Mullin 1963, Frost 1972, 1977). Large particles are detected and captured singularly, whereas particles below a certain size threshold are passively filtered (Price \& Paffenhöfer 1985). However, this behavior often cannot be demonstrated in nature (Poulet 1978, Harris 1982). Particles below about $2 \mu \mathrm{m}$ are ineffectively removed from the water by small, adult copepods (Bartram 1981). Particles which are large enough to be captured may be ignored or rejected after capture, based on taste or a water-soluble, noxious, secondary metabolite (Fiedler 1982, Huntley 1982, Huntley et al. 1986, Sykes \& Huntley 1987). During 'Eumenides III', we were unable to demonstrate that either cell size or the presence of noxious species provided a reason for copepods to prefer the surface layers over the microplankton biomass maximum or vice-versa.

Zooplankton, as heterotrophs, must obtain their nitrogenous precursors for protein synthesis from their diet. Although the specific nitrogen requirements of marine invertebrates are poorly understood (Roman 1983), individual growth and reproduction of zooplankton are limited when dietary nitrogen is insufficient (e.g. Checkley 1980, Roman 1984). However, growth and reproduction are not simple monotonically increasing functions of the nitrogen content of the food. The maximum gross growth efficiency $\left(K_{1}\right.$, growth/ingestion) of a marine rotifer in culture was achieved with a ('balanced') diet containing roughly equal proportions of carbohydrate, protein and lipid (i.e. $1 / 3,1 / 3,1 / 3$ by weight; Scott 1980).

During 'Eumenides III', no one depth could be identified as containing a balanced diet - one where the 3 macromolecule components were in roughly equal proportions. The particulate protein and carbohydrate concentrations were always much larger (and more similar) than the concentration of particulate lipid. The enrichment of protein and carbohydrate per unit carbon tended in opposite directions with depth. An indiscriminate particle-grazer would have ingested more dietary protein per unit carbon at the microplankton biomass maximum and more carbohydrate per unit carbon at the surface.

Copepods have been observed in the laboratory to ingest faster growing cells at higher rates than their slower growing conspecifics (Mullin 1963, Houde \& Roman 1987, Cowles et al. 1988). In 2 of the studies, a major difference between the cells was the greater protein content of the faster growing cells, and Cowles et al. (1988) hypothesized that the higher protein and free amino acid concentration of these cells (and cell exudate) resulted in a different near-field perception of the cells by grazers. During 'Eumenides III', phytoplankton growth rate and particulate nitrogen (and particulate protein) increased in opposing directions; phytoplankton growth rates were usually greatest above the plant biomass maximum, while nitrogen per unit carbon was greatest within the plant biomass maximum.

Finally, the concentrations of both particulate carbon and nitrogen were greatest at the plant biomass maximum. Thus we found no clear evidence contradicting 
the simple hypothesis that the plant biomass maximum is a good place to feed, though less predictable in floral composition than shallower layers.

Acknowledgements. We gratefully acknowledge the hard work of P. Andrews, M. Lenihan, J. Nelson, J. Schmitt, M. Van Nostrand, W Wakefield, and the captain and crew of the RV 'Robert Gordon Sproul' Major equipmeni loans from R. Eppley, L. Haury, and the Marine Ecological Consultants (Encinitas, Calif.) facilitated our sampling. We also thank E. Stewart who was responsible for computer processing of the data collected, and M. Gordon, M. Greene, B. Hardie, C. Lundy and D. Osborn who typed our manuscript. The manuscript has benefitted from criticisms offered by Wm. Balch, $R$ Eppley, J. McGowan, J. Nelson, R. Olshen, P. Ortner, R. Pinkel. M. Roman, S. Shapiro, and 3 anonymous reviewers This project was funded by NSF grant, OCE 83-15190, to M Mullin.

\section{LITERATURE CITED}

Anderson, G. C., Frost, B. W., Peterson, W. K. (1972). On the vertical distribution of zooplankton in relation to chlorophyll concentration. In: Takenouti, A. Y (ed.) Biological oceanography of the northern North Pacific Ocean. Idemitsu Shoten, Tokyo, p. 341-345

Azam, F., Hodson, R. E. (1977). Size distribution and activity of marine microheterotrophs. Limnol. Oceanogr. 22: 492-501

Barlow, R. G. (1984a). Physiological responses of phytoplankton to turbulent and stable environments in an upwelling region. J. Plankton Res. 6: 385-397

Barlow, R. G. (1984b). Time series uptake of carbon into photosynthetic products of Benguela phytoplankton populations. J. Plankton Res. 6: 435-442

Bartram, W. C. (1981). Experimental development of a model for the feeding of neritic copepods on phytoplankton. $J$ Plankton Res. 3: 25-51

Beers, J. R., Reid, F. M. H., Stewart, G. L. (1980). Microplankton population structure in southern California nearshore waters in late spring. Mar. Biol. 60: 209-226

Beers, J. R., Reid, F. M. H., Stewart, G. L. (1982). Seasonal abundance of the microplankton population in the North Pacific central gyre. Deep Sea Res. 29A: 227-245

Checkley, Jr, D. M. (1980). The egg production of a marine planktonic copepod in relation to its food supply: laboratory studies. Limnol Oceanogr. 25: 430-446

Conover, R. J. (1968). Zooplankton - life in a nutritionally dilute environment. Am. Zool. 8: 107-118

Conover, R. J., Mayzaud, P. (1984). Utilization of phytoplankton by zooplankton durng the spring bloom in a Nova Scotia inlet. Can. J. Fish. Aquat Sci. 41: 232-244

Cowles, T. J., Olson, R. J., Chisholm, S. W. (1988). Food selection by copepods: discrimination between cells on the basis of food quality. Mar. Biol. (in press)

Cuhel, R. L., Ortner, P. B., Lean, D. R. S. (1984). Night synthesis of protein by algae. Limnol. Oceanogr. 29: 731744

Cullen, J. J. (1982). The deep chlorophyll maximum: comparing vertical profiles of chlorophyll a. Can. J. Fish. Aquat. Sci. 39: 791-803

Cullen, J. J., Eppley, R. W. (1981) Chlorophyll maximum layers of the Southern California Bight and possible mechanisms of their formation and mantenance. Oceanologica Acta 4: 23-32

Cullen, J. J., Reid, F. M. H., Stewart, E. (1982). Phytoplankton in the surface and chlorophyll maximum off southern California in August, 1978. J. Plankton Res. 4: 665-694

Dagg, M. J., Wyman, K. D. (1983). Natural ingestion rates of the copepods Neocalanus plumchrus and $N$. cristatus calculated from gut contents. Mar. Ecol. Prog. Ser. 13: 37-46

Dorsey, T E., McDonald, P. W., Roels, O. A. \{1977\}. A heated Biuret-Folin protein assay which gives equal absorbance with different proteins. Analyt. Biochem. 78: 156-164

Dortch, Q. (1987). The biochemical composition of plankton in a subsurface chlorophyll maximum. Deep Sea Res. 34 $705-712$

Dortch, Q., Clayton, Jr, J. R., Thoreson, S. S., Ahmed, S. I (1984). Species differences in accumulation of nitrogen pools in phytoplankton. Mar. Biol. 81: 237-250

Dubinsky, Z, Aaronson, S. (1979). Increase of lipid yields from some algae by acid extraction. Photochem. 18: 51-52

Dubois, M., Gilles, K. A., Hamilton, J. K., Rebers, P. A., Smith, F. (1956). Colorimetric method for determination of sugars and related substances. Analyt. Chem. 28: 350-355

Eppley, R. W., Renger, E. H., Harrison, W G. (1979). Nitrate and phytoplankton production in the Southern California coastal waters. Limnol. Oceanogr. 24: 483-494

Eppley, R. W., Harrison, W. G., Chisholm, S. W., Stewart, E. (1977). Particulate organic matter in surface waters off Southern California and the relationship to phytoplankton. J. mar. Res. 35: 671-696

Eppley, R. W., Reid, F. M. H., Cullen, J. J., Winant, C. D., Stewart, E. (1984). Subsurface patch of a dinoflagellate (Ceratium tripos) off Southern California: patch length, growth rate, associated vertically migrating species. Mar. Biol. 80: 207-214

Fiedler, P. C. (1982). Zooplankton avoidance and reduced grazing pressure responses to Gymnodinium splendens (Dinophyceae). Limnol. Oceanogr 27: 961-965

Fiedler, P. C. (1983). Fine-scale spatial patterns in the coastal epiplankton off southern California. J. Plankton Res. 5: 865-879

Frost, B. W. (1972). Effects of size and concentration of food particles on the feeding behavior of the marine planktonic copepod Calanus pacificus. Limnol. Oceanogr 17 . 805-815

Frost, B. W (1977). Feeding behavior of Calanus pacificus in mixtures of food particles. Limnol. Oceanogr 22: 472-491

Fuhrman, J. A., Ammerman, J. W., Azam, F. (1980). Bacterioplankton in the coastal euphotic zone: distribution, activity and possible relationships with phytoplankton. Mar. Biol. 60: 201-207

Furuya, K., Marumo, R. (1983). The structure of the phytoplankton community in the subsurface chlorophyll maxima in the western North Pacific Ocean. J. Plankton Res. 5: 393-406

Gieskes, W W., Krady, G. W (1986). Floristic and physiological differences between shallow and the deep nanophytoplankton community in the euphotic zone of the open tropical Atlantic revealed by HPLC analysis of pigments. Mar, Biol. 91: 567-576

Goodman, D., Eppley, R. W., Reid, F. M. H. (1984). Summer plankton assemblages and their environmental correlates in the Southern California Bight. J. mar Res. 42: 1019-1049

Hakanson, J. L. (1987). The feeding condition of Calanus pacificus and other zooplankton in relation to phytoplankton pigments in the California Current. Limnol. Oceanogr 32: $881-894$

Handa, N. Tominaga, H. (1969). A detailed analysís of carbohydrates in marine particulate matter. Mar. Biol. 2: 228-235 
Harding, Jr, L. W., Meeson, B. W., Fisher, Jr, T R. (1985). Patterns of photosynthetic carbon metabolism in lightlimited phytoplankton. Mar. Biol. 89: 121-133

Harris, R. P. (1982). Comparison of the feeding behavior of Calanus and Pseudocalanus in two experimentally manipulated enclosed systems. J. mar biol. Ass. U.K. 62: 71-91

Herman, A. W., Platt, I (1983). Numerical modelling of diel carbon production and zooplankton grazing on the Scotian shelf based on observational data. Ecol. Modelling 18: $55-72$

Herman, A. W., Sameoto, D. D., Longhurst, A. R. (1981). Vertical and horizontal distribution patterns of copepods near the shelf break south of Nova Scotia. Can. J. Fish. Aquat. Sci. 38: 1065-1076

Hitchcock, G. L. (1980). Diel variation in chlorophyll a, carbohydrate and protein content of the marine diatom Skeletonema costatum. Mar Biol. 57: 271-278

Hitchcock, G. L., Goldman, J. C., Dennett, M. R. (1986). Photosynthetic partitioning in cultured marine phytoplankton: metabolic patterns in a marine diatom under constant and variable light intensities. Mar. Ecol. Prog. Ser, 30: 77-84

Houde, S. E. L., Roman, M. R. (1987). Effects of food quality on the functional ingestion response of the copepod Acartia tonsa. Mar Ecol. Prog. Ser. 40: 69-77

Huntley, M. E (1982). Yellow water in La Jolla Bay, California, July 1980. II. Suppression of zooplankton feeding. J. exp. mar. Biol. Ecol. 63: 81-91

Huntley, M. E., Sykes, P., Rohan, S., Marin, V. (1986). Chemically mediated rejection of dinoflagellate prey by the copepods Calanus pacificus and Paracalanus parvus: mechanism, occurrence and significance. Mar. Ecol. Prog. Ser 28: 105-120

Jamart, B. M., Winter, D. F., Banse, K., Anderson, G. C., Lam., R. K. (1977). A theoretical study of phytoplankton growth and nutrient distribution in the Pacific Ocean off the northwestern U.S. Coast. Deep Sea Res. 24A: 753-773

Kierstead, H., Slobodkin, L. B. (1953). The size of water masses containing plankton blooms. J. mar. Res. 12 $141-147$

Lasker, R. (1975). Field criteria for survival of anchovy larvae: the relation between inshore chlorophyll maximum layers and successful first feeding. Fish. Bull. U.S. 73: 453-462

Li, W. K. W., Harrison, W. G. (1982). Carbon flow into the endproducts of photosynthesis in short and long incubations of a natural phytoplankton population. Mar. Biol. 72: $175-182$

Li, W K. W., Platt, T (1982). Distribution of carbon among photosynthetic end-products in phytoplankton of the eastern Canadian arctic. J. Phycol. 18: 466-471

Longhurst, A. R. (1976). Interactions between zooplankton and phytoplankton profiles in the eastern tropical Pacific Ocean. Deep Sea Res. 23A: 729-754

Morris, I. (1981). Photosynthesis products, physiological state, and phytoplankton growth. In: Platt, T (ed.) Physiological bases of phytoplankton ecology. Can. Bull. Fish. Aquat. Sci. 210: 83-102

Morris, I., Skea, W. (1978). Products of photosynthesis in natural populations of marine phytoplankton from the Gulf of Maine. Mar. Biol. 47: 303-312

Mullin, M. M. (1963). Some factors affecting the feeding of marine copepods of the genus Calanus. Limnol. Oceanogr. 8: $239-250$

Mullin, M. M. (1979). Longshore variation in the distribution of plankton in the Southern California Bight. CalCOFI Rept. 20: 120-124

Mullin, M. M., Brooks, E. R. (1976). Some consequences of distributional heterogeneity of phytoplankton and zooplankton. Limnol. Oceanogr 21. 784-796

Mullin, M. M., Brooks, E. R., Reid, F. M. H., Napp, J., Stewart, E. F. (1985). Vertical structure of nearshore plankton off Southern California: a storm and a larval fish food web. Fish. Bull. U.S. 83: 151-170

Napp, J. M. (1986). The vertical distribution and in situ feeding of marine particle-grazers in relation to their food, the microplankton. Ph. D. dissertation, University of California, San Diego

Napp. J. M. (1987). Primary productivity maxima in the Southern California Bight: distribution, predicted depth and nutritional content. Oceanologica Acta 10: 329-337

Napp, J. M., Brooks, E. R., Matrai, P., Mullin, M. M. (1988). Vertical distribution of marine particles and grazers. II. Relation of grazer distribution to food quality and quantity. Mar Ecol. Prog. Ser. 50: 59-72

Ortner, P. B., Wiebe, P. H., Cox, J. L. (1980). Relationship between oceanic epizooplankton distributions and the seasonal deep chlorophyll maximum in the northwestern Atlantic Ocean. J. mar. Res. 38: 507-531

Pande, S. V., Parvin Khan, R., Venkitasubramanian, T. A. (1963). Microdetermination of lipids and serum total fatty acids. Analyt. Biochem. 66: 415-423

Parsons, T R., LeBrasseur, R. J., Fulton, J. D. (1967). Some observations on the dependence of zooplankton grazing on the cell size and concentration of phytoplankton blooms. J. oceanogr. Soc. Japan 23: 10-17

Poulet, S. A. (1978). Comparison between five co-existing species of marine copepods feeding on naturally occurring particulate matter. Limnol. Oceanogr. 23: 1126-1143

Price, H. J., Paffenhöfer, G.-A. (1985). Perception of food availability by calanoid copepods. Arch. Hydrobiol. Beih. 21: $115-124$

Redalje, D. G., Laws, E. A. (1983). The effects of environmental factors on growth and the chemical and biochemical composition of marine diatoms. I. Light and temperature effects. J. exp. mar. Biol. Ecol. 68: 59-79

Reid, F. M. H. (1983). Biomass estimation of components of the marine nannoplankton and picoplankton by the Utermöhl technique. J. Plankton Res. 5: 235-252

Reid, F. M. H., Lange, C. B., White, M. M. (1985). Microplankton species assemblages at the Scripps Pier from March to November 1983 during the 1982-1984 El Nino event. Botanica mar 28: 443-452

Reid, F. M. H., Stewart, E., Eppley, R. W., Goodman, D. (1978). Spatial distribution of phytoplankton species in chlorophyll maximum layers off southern California. Limnol. Oceanogr. 23: 219-227

Revelante, N., Gilmartin, M. (1973). Some observations on the chlorophyll maximum and primary production in the eastern North pacific. Int. Revue ges. Hydrobiol. 58: 819-834

Rivkin, R. B. (1985). Carbon-14 labelling patterns of individual marine phytoplankton from natural populations. Mar. Biol. 89: $135-142$

Roman, M. R. (1983). Nitrogenous nutrition of marine invertebrates. In: Carpenter, E. J., Capone, D. G. (eds.) Nitrogen in the sea. Academic Press, New York, p. 347-383

Roman, M. R. (1984). Utilization of detritus by the copepod, Acartia tonsa. Limnol. Oceanogr. 29: 949-959

Roman, M. R., Yentsch, C. S., Gauzens, A. L., Phinney, D. A. (1986). Grazer control of the fine-scale distribution of phytoplankton in warm-core Gulf Stream rings. J. mar. Res. 44: 795-813

Scott, J. M. (1980). Effect of growth rate of the food alga on the growth/ingestion efficiency of a marine herbivore. J. mar. Biol. A.ss. U.K. 60: 681-702 
Sharp, J. H. (1974). Improved analysis for 'particulate' organic carbon and nitrogen from seawater. Limnol. Oceanogr. 19: 984-989

Sokal, R. R., Sneath, P. H. A. (1963). Principles of numerical taxonomy. W H. Freeman and Co

Strathmann, R. R. (1967). Estimating the organic carbon content of phytoplankton from cell volume or plasma volume. Limnol. Oceanogr. 12: 411-418

Strickland, J. D., Parsons, T. R. (1968). A practical handbook of seawater analysis, 1stedn. Bull. J. Fish. Res. Bd Can. No. 167

Sykes, P. F., Huntley, M. E. (1987). Acute physiological reactions of Calanus pacificus to selected dinoflagellates: direct observations. Mar. Biol. 94:19-24
Terry, K. L., Hirata, J., Laws, E. A. (1983). Light-limited growth of two strains of the marine diatom Phaeodactylum tricornutum Bohlin: chemical composition, carbon partitioning and the diel periodicity of physiological processes. J. exp. mar Biol. Ecol. 68: 209-227

Venrick, E. L. (1982). Phytoplankton in an oligotrophic ocean: observations and questions. Ecol. Monogr. 52: 129-154

Venrick, E. L., McGowan, J. A., Mantyla, A. W (1973). Deep maxima of photosynthetic chlorophyll in the Pacific Ocean. Fish. Bull. U.S. 71: 41-52

Whittaker, R. H. (1952). A study of summer foliage insect communities in the Great Smokey Mountains. Ecol. Monogr. 22: 1-44.

This article was submitted to the editor; it was accepted for printing on September 12, 1988 